\title{
IMPROVEMENT OF THE CONSTRUCTION PROCESS WITH IMPLEMENTATION OF REGULATORY STANDARD No. 35 (NR-35): CASE STUDY
}

\author{
Ana Caroline da Silva Taumaturgo ${ }^{1}$, David Barbosa de Alencar², Jorge de Almeida Brito Júnior ${ }^{3}$ \\ Williams Ícaro Miranda da Silva ${ }^{4}$ and Sinndy Rossaly Cabral de Oliveira ${ }^{5}$
}

\section{1,2,3,4,5 Blauro Cardoso de Mattos Higher Education Institute - FASERRA. Manaus-Amazonas, Brazil.}

Email: caroline.taumaturgo@gmail.com,david002870@hotmail.com,jorgebritojr@gmail.com,williams.icaro@gmail.com, srossaly@gmail.com

Received: Aug 16 ${ }^{\text {th }}, 2019$

Accepted: Aug 30th 2019

Published: December 02 ${ }^{\text {th }}, 2019$

Copyright (C2016 by authors and Galileo Institute of Technology and Education of the Amazon (ITEGAM).

This work is licensed under the Creative Commons Attribution International License (CC BY 4.0).

https://creativecommons.org/licen ses/by/4.0/

\begin{abstract}
In many construction texts, the risk of falling becomes worrying, often overlooked and / or overlooked as an employee or employee. The MTE (Ministry of Labor and Employment) presents $30 \%$ of occupational investments that occur each year and falls from a height. In order to reduce the rate of falls, a Regulatory Standard No. 35, located for work at height, with a reference capacity for this work was created. safety. And with the expansion over the years, an increasing number of accidents have been added, and so on, increasingly frequent. This work aims to implement a Regulatory Standard - NR 35 for an improvement of the work execution process.
\end{abstract}

Keywords: Standards (NR-35), Construction, Safety work.

\section{INTRODUTION}

With the warming of the construction sector not taking place in recent years, A large number of jobs were needed to meet all the demand. Offered As well as the significant increase in demand for labor, it is having to be more on a job of flower beds works, that due to own nature of the work that entails risks and may result in accidents of all kinds. Other determining factors that affect the industry are: employee turnover, ham as in environments, work processes, and as part failure to comply with basic worker protection standards [1].

With the growth of the construction industry it was observed that this The sector is one of the ones with the most accidents without work, so it is necessary to review the ways in which work is performed and the creation of standards that minimum security settings to be implemented to decrease a number of accidents. For this on June 8, 1978 was Ordinance No. 3.214, as Regulatory Standards, which have the purpose of to regulate occupational health and safety procedures. Such parameter standards for the different activities you can perform your activity to the best of your ability and with the maximum productivity, reducing / eliminating accidents. Beyond The rights and duties of employees and employers. [2].

This work aims to implement the regulatory standard (NR35), in order to better the process of execution of the works and bring benefits and safety to employees of a particular company.

\section{DEVELOPMENT}

The Brazilian scenario is very conducive to the wind sector and some characteristics conspire to this, such as the properties of the winds that have predominantly uniform direction throughout the year and constant across all seasons, thereby making it far more profitable and productive than in compared to a European plant for example, where its winds do not have such good properties and also the cost savings due to auctioning policies making it one of the cheapest energy sources in the country today [3].

Over the past twelve years, the average percentage of its share in the product gross domestic product (GDP) was approximately 5.1\%.[3] In 2011, this percentage 5,8\% and $21 \%$ of the industrial sector's contribution to this index.

When considering the entire productive chain of Industry Civil Construction, which includes the production and marketing 
of materials, services, machines and equipment, comes to $8.1 \%$ of the same indicator, or R \$ 297.6 billion.

For [5]"work safety is the science that operates on prevention of industrial accidents resulting from operational risk factors." [5] As stresses, there are numerous situations of risk in working environments that are liable to cause accidents at work, and therefore, the deployment of analysis of risk factors in all activities, with the objective of identify such aggressive factors and promote all the necessary prevention measures.

For [7] according to, security means a trust in loss prevention, a State and a condition of protection. Safety includes the prevention of early way of accidents by applying preventive and corrective measures risk conditions that can lead to accidents. [1]

According, [5] the accident at work is defined as: from a legal standpoint, the work is what accident occurs at work in the service of the company, causing personal injury or functional disturbance that causes the death or loss or reduced, permanent or temporary, of the capacity for work (art. 19 of the law 8,213/91).

The following will be presented concepts extracted from NR-35, NR-18, NR-6, as well as information goes up individual protection equipment, preventive measures and preliminary analysis of risks.

\section{II.1 REGULATORY STANDARD No 35}

The Regulatory Standard (NR-35) establishes the minimum requirements of security to the employee involved directly and indirectly in work at height, all that, involving the planning, execution and organization. Not correct application of NR 35 may be related to lack of information or even the resistance to change the habits that were fairly entrenched, especially when workers are used to dealing with time, causing it to not notice the imminence of the risk and end up failing to carry out safety procedures. So, the importance of supervision, too.

[4] Responsibilities according to NR-35 (2012), it is the responsibility of the employer to ensure the implementation of the protective measures laid down in this standard, to ensure the realization of the risk analysis and, where applicable, the issuance of the work permit-EN; Develop operating procedure for routine activities of work at height; ensure prior assessment of the conditions in the place of work at height; adopt the necessary measures to monitor compliance with the protective measures laid down in this standard by the contractors;

Responsibilities according to NR-35 (2012) [3] it is the responsibility of the employer to ensure the implementation of the protective measures laid down in this standard, to ensure the realization of the risk analysis and, where applicable, the issuance of the work permit-EN; Develop operating procedure for routine activities of work at height; ensure prior assessment of the conditions in the place of work at height; adopt the necessary measures to monitor compliance with the protective measures laid down in this standard by the contractors;

As stated in the Manual to Aid in the interpretation and application of the NR 35, work at height is, therefore, any work performed within higher level to $2.0 \mathrm{~m}$ (two meters) of the reference surface and providing risk of falling. Access activities and output of the worker of this site should also respect and meet this standard. [3] All activities with risk for workers must be preceded by analysis and the worker must be informed about these risks and the protective measures implemented by the company, as it establishes the NR1. The provisions of NR35 doesn't mean it should not be adopted measures to eliminate, reduce or neutralize the risks in the work carried out at a height less than or equal to 2 , $0 \mathrm{~m}$.

In compliance with the guidelines established in NR 35, the employer and the employees involved in the construction industry, will be contributing to the prevention of industrial accidents caused by falls in work at height, with adequate security, accidents can be avoided . Job security is a set of technical measures, educational, psychological and medical used to prevent accidents, is eliminating unsafe conditions of the environment, is instructing or convincing people the use of practices preventive. [2]

Safety and hygiene are key factors in the prevention of accidents and the protection of employee health, since their actions and guidelines can prevent human suffering and economic waste harmful to the companies and to the own country. [6] The health and safety of employees constitute one of the main bases for the prevention of appropriate work force. Simple, hygiene and safety are two related activities, in order to ensure conditions able to retain the degree of employees ' health. [1]

\section{II.2 PERSONAL PROTECTIVE EQUIPMENT-PPE}

Personal protective equipment-PPE are specified and regulated by Regulatory Norm $\mathrm{n}^{\circ} 6$. The same sets IPE as "any device or product of single use used by the worker, for the protection of risks likely to threaten the safety and health of the worker." The company's duty to the free provision of PPE's to employees, and must be in perfect condition and operation. The NR-6 highlights that all personal protective equipment must have the certificate of approval-CA, approved by the Ministry of labor and employment. The types of PPE's are defined as the services or risks that may threaten the health and safety of employees. By NR6 defines the IPE as protection on the part of the body, being the following:

1) Head protection: hood and helmets;

2) Eye and face protection: safety glasses, face shields, welding mask and face shield;

3) Respiratory protection: masks and filters;

4) Upper limb protection: gloves, hoses, clamp and BA;

5) Lower limb protection: footwear (boots and footwear), socks, leggings and pants;

\section{II.2.1 EPI FOR HEAD PROTECTION}

In accordance with Annex I of NR 6, helmet and hood are used for head protection. The helmets Act protecting against impacts from objects on the skull, electroshock and protection of the face and skull against operatives thermal. While the hood protects the skull and neck against risks of thermal sources, abrasive agents and scorers, in addition to protection against moisture originating from operations with use of water. Figure 01 shows a helmet.

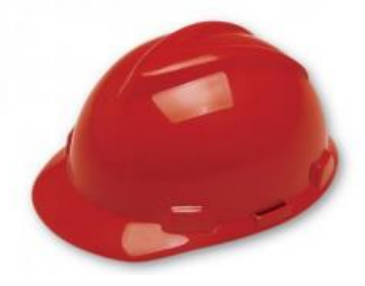

Figure 1: Protection helmet for head. Source: [8]. 


\section{II.2.2 PPE FOR FALL PROTECTION WITH DIFFERENCE OF LEVEL}

The security belt with locking device-fall is the PPE required in activities at height. The security belt with locking device-protects the user against falls in operations with vertical or horizontal movement. Other personal protection device used in work at height is the security belt with lanyard.
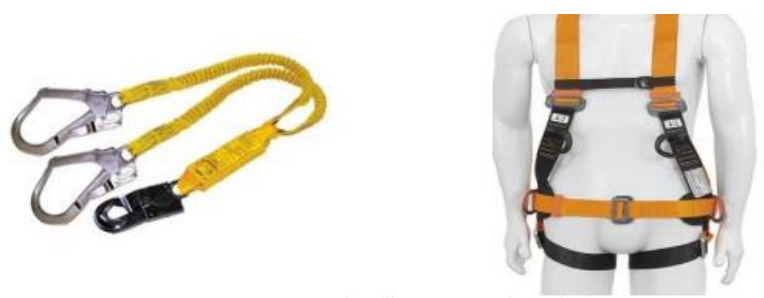

Figure 2: Safety Lanyard with energy absorber and type safety belt parachutist.

Source: [8].

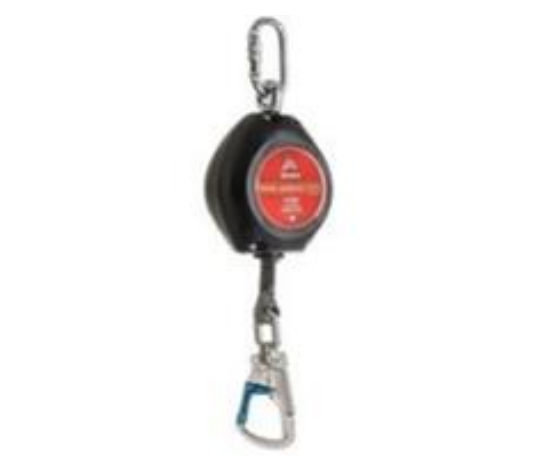

Figure 03: Device used to lock retractable fall. Source: [8].

\section{II.2.3 SCAFFOLDING}

In construction, in many phases of a work you must use scaffolding to perform certain tasks, however, these scaffolds should follow NR18 regulations to ensure total security to the worker. In your item 18.15, regulatory standard stipulates the operational requirements of the scaffolding, such structures need to be properly sized to support the workloads that are subject. The installation of the floor scaffolding must be level and have full lining, slip-resistant, and secured safely. The wood used in the scaffolding must be dry and of good quality, without knots or cracks. Around the perimeter of the scaffold you must use railing systems and footer, except for the side in which you work. The item 18.15 on scaffolding, regulating the requirements and restrictions of use of the various types of scaffolding, then listed some subitems:

\section{II.2.3.1 SCAFFOLDING SIMPLY SUPPORTED}

According to the standard work on scaffolds is prohibited on the periphery of the building without adequate protection secured to the structure of the same. It is prohibited the displacement of structures of the scaffolding with workers about the same. The structure of the scaffolding must be secured to the building by means of mooring and trucking in order to resist efforts to that subject. The towers of scaffolding may not exceed in height, 4 (four) times the smallest dimension of the base of support, if not cable-stayed.

\section{II.2.3.2 SCAFFOLDING FACADE COMPOSITE}

The scaffolding facade composite should not receive loads higher than those specified by the manufacturer. Your load must be distributed evenly, without obstructing the movement of people and be limited by the resistance of the covering of the work platform. The vertical access to the scaffolding facade composite should be made on the corporate ladder your own structure or through access tower. Scaffolding facade composite panels intended to support the floors and/or work as locking, after assembled to amounts, must be counterparts or locked with screws, brackets or similar.

\section{II.2.3.3 MOBILE SCAFFOLDING}

Scaffolding castors must be fitted with locks to prevent accidental displacement. The mobile scaffolding can only be used on flat surfaces.

\section{II.2.3.4 SCAFFOLDING IN SWING}

The scaffolding in the balance sheet should have fixing system to the building structure capable of supporting 3 (three) times requesting efforts. The scaffold structure must be properly brace and anchored, in such a way as to eliminate any oscillations.

The item of 35.5 NR 35 establishes that the IPE, anchoring systems and accessories must be specified and selected considering your efficiency, comfort, the applied load. Personal protective equipment shall be subjected to periodic inspection in order to observe any defects and deformations. And always before starting the activities the EPI, anchoring systems and accessories should be inspected.

All who submit defects or imperfect should be discarded and unused. In accordance with item 35.5.3, the seat belts must be of type parachutist and have device for anchoring system connection. Throughout the risk exposure, the worker must be connected to the system. In addition, the lanyard and the device crashes falls must be fixed above waist level, ensuring fall height restriction and ensure that, in case of a fall, minimize the chances of workers striking the bottom structure. The NR35, requires the use of energy absorber in the following situations: fall factor greater than 1, the length of the lanyard is greater than 0.9 . The anchor points must be selected by professional enabled, must possess resistance to withstand the maximum load applicable and be inspected for your integrity.

\section{METHODOLOGY}

The proposed work was accomplished through a visit in loco and the Office in a company in the business of construction and a critical and reflective about the scientific subject obtained from the references.

The company is taken as a reference to this study is located in the city of Manaus/AM and works in the construction business, where information was obtained for the completion of this work. The company is a company in the business of construction. Your CNAE-4120-4-00 as NR-4 Specialized Security Service and occupational medicine-SESMT, company's risk grade 3 and due to the number of employees, the more the level of risk it is necessary to have 1 (one) professional job security. This organization is considered of medium businesses and has as its main activity the maintenance and renovation of buildings and building corrective federal agencies. 
In the process of this work, there was an interview with the technique of job security along with the safety engineer Job, to see how it runs the work of staff running the service on time, which allowed the deepening of knowledge and qualitative results concerning the handling of standard Regulate within this company.

The activities carried out today by the company is cleaning the facade, painting in schools and various other work at height resulting urgently the implementation of regulatory standard $\mathrm{Nr} 35$.

During the process of drafting this article was carried out a questionnaire with the safety technique for analysis of what the company follows for regulatory standard NR-35:

Table 1: Simplified questionnaire Results to standard NR 35 data collection.

\begin{tabular}{|c|c|c|}
\hline DESCRIPTION & YES & NO \\
\hline $\begin{array}{c}\text { In all work involving risk of falling above } 2 \mathrm{~m} \text { are } \\
\text { obeyed the NR 35? }\end{array}$ & & $\mathbf{X}$ \\
\hline $\begin{array}{c}\text { The company develops regularly work at height } \\
\text { activities? }\end{array}$ & $\mathbf{X}$ & \\
\hline $\begin{array}{l}\text { There are operational procedures for the routine } \\
\text { activities of work at height? }\end{array}$ & & $\mathbf{X}$ \\
\hline $\begin{array}{l}\text { Exists in the company prior study of the conditions in } \\
\text { the place where it will be executed the work in time? }\end{array}$ & $\mathbf{X}$ & \\
\hline $\begin{array}{l}\text { The company adopts necessary measures for the } \\
\text { realization of a safe job? }\end{array}$ & & $\mathbf{X}$ \\
\hline $\begin{array}{c}\text { The company adopts necessary measures to track } \\
\text { compliance with the protective measures laid down in } \\
\text { this standard to contractors? }\end{array}$ & & $\mathbf{X}$ \\
\hline $\begin{array}{l}\text { Workers have access to up-to-date information about } \\
\text { the risks and control measures? }\end{array}$ & $\mathbf{X}$ & \\
\hline $\begin{array}{l}\text { The company ensures that any work at height only } \\
\text { begins after adopted protection measures defined on NR } \\
35 ?\end{array}$ & & $\mathbf{X}$ \\
\hline $\begin{array}{l}\text { The company ensures the suspension of work at height } \\
\text { when checking situation or unforeseen risk condition, } \\
\text { whose elimination or immediate neutralization is not } \\
\text { possible? }\end{array}$ & $\mathbf{X}$ & \\
\hline $\begin{array}{l}\text { The company establishes a system for the authorization } \\
\text { of workers to work at height? }\end{array}$ & $\mathbf{X}$ & \\
\hline $\begin{array}{l}\text { The company ensures that all work at height is carried } \\
\text { out under supervision, whose shape will be defined by } \\
\text { risk analysis according to the peculiarities of the } \\
\text { activity? }\end{array}$ & & $\mathbf{X}$ \\
\hline $\begin{array}{c}\text { The company ensures the Organization and archiving of } \\
\text { documentation provided in NR } 35 ?\end{array}$ & & $\mathbf{X}$ \\
\hline $\begin{array}{l}\text { Workers with the dispatch procedures on work at } \\
\text { height, collaborating with employer? }\end{array}$ & $\mathbf{X}$ & \\
\hline $\begin{array}{l}\text { Workers have the right to interrupt its activities by } \\
\text { exercising the right of refusal, where they find evidence } \\
\text { of serious and imminent risks to your health and safety } \\
\text { or that of others, communicating to your superior } \\
\text { immediately hierarchical, that it will make the } \\
\text { appropriate measures? }\end{array}$ & & $\mathbf{X}$ \\
\hline $\begin{array}{l}\text { The workers are instructed to protect your health and } \\
\text { safety and that of others who may be affected by your } \\
\text { actions or omissions at work? }\end{array}$ & & $\mathbf{X}$ \\
\hline $\begin{array}{l}\text { The employer promoted workers ' capacity for work at } \\
\text { height? }\end{array}$ & & $\mathbf{X}$ \\
\hline
\end{tabular}

Source: Authors, (2019).

After the collection has been found that the company does not have an integrated system for regulatory norm $\mathrm{n}^{\circ} 35$, and does not have enough documentation for this work at height, was proposed the deployment of standards aimed at safety and convenience for enterprise and employee.

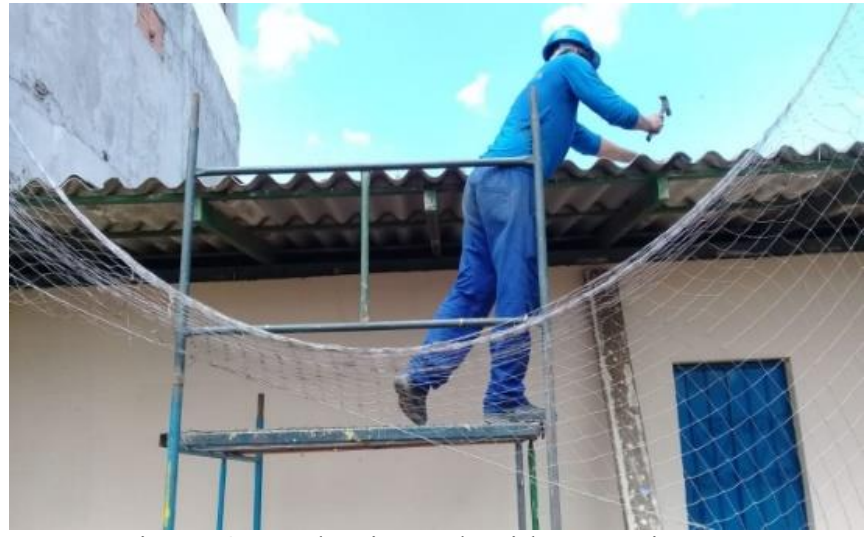

Figure 4: Worker in work without equipment. Source: Authors, (2019).

And the lack of integrated system of regulatory standard number 35 made the developer of this comp to suffer a serious accident as the diary below technical report of enterprise security.

The data obtained in this diary shows the lack of enterprise and professional preparation to run such services on time which resulted in the crash of the professional of this company.

Table 2: Diary of works (the crash Reports).

\begin{tabular}{|c|c|}
\hline \multicolumn{2}{|c|}{ Tasks performed } \\
\hline Description & \\
\hline $\begin{array}{c}\text { Application of mass execution and } \\
\text { external and internal painting of the } \\
\text { school Fr. silvio. }\end{array}$ & \\
\hline
\end{tabular}

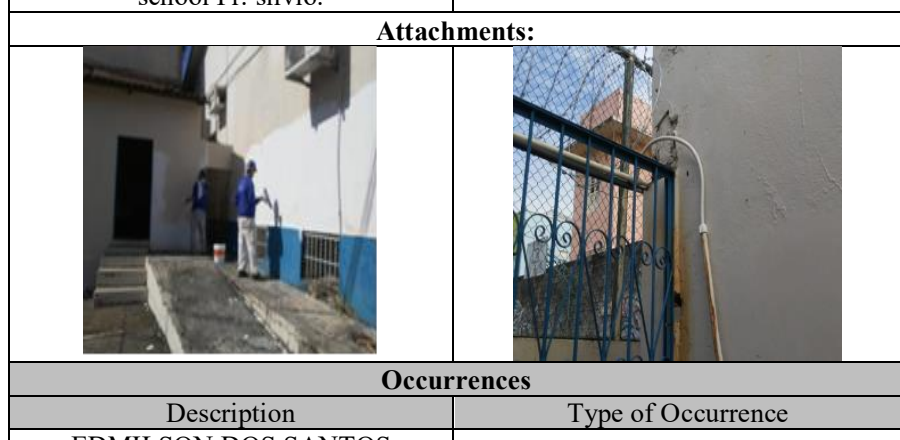

EDMILSON DOS SANTOS

accident occurred on stairs metallic,

where the same was running a grid painting 2 meters from the floor

level, unfortunately scareware ladder

on the concrete floor, causing a

sudden drop from the developer to the ground, the same $\mathrm{fHi}$ oriented does not move and not anybody touch it, until the arrival of medical team (SAMU), medical team arrived

ACTIVITY CARRIED OUT WITH DIFFERENT LEVEL BEING HELD ONLY BY ONE DEVELOPER AND INATTENTION.

at the crash site quickly, conducted mobilization procedures led the developer to the hospital closest accompanied with represent of the company.

\begin{tabular}{|c|c|c|}
\hline \multicolumn{3}{|c|}{ Team involved } \\
\hline Code & Description & Quantity used \\
\hline & CIVIL ENGINEER & 1,0 \\
\hline & MASTER BUILDER & 1,0 \\
\hline \multicolumn{3}{|c|}{ Equipment's utilized } \\
\hline Code & Description & Quantity used \\
\hline & HELMET & 1,0 \\
\hline & GLOVES & 2,0 \\
\hline & MASK & 1,0 \\
\hline & SAFETY GLASSES & 1,0 \\
\hline
\end{tabular}

Source: Authors, (2019).

The non-conformities observed in this condition match the lack of preparation of the company and its employees to carry out 
work at height, lack of PPE and specific devices to perform activity in time, in addition to failing tests to verify that the specific person who will perform in service time fit for activity. The PPE and assistance to perform such activities as scaffolds, stairs became the biggest ally of the professionals who are constantly exposed to risks in the workplace, case of forest workers.

In General, the use of individual protection equipment and devices to aid generates a lot of benefits to workers and employers. Based on that what has been proposed for this company, was the regulatory standard NR 35 deployment to all employees and agents of the company, as the process below should be elaborated a prior assessment serves to determine what and where are the risks related to fall inside the construction site. For both, the NR 35 requires hear all activities that will happen during the work. This procedure must be done by professional work safety enabled.

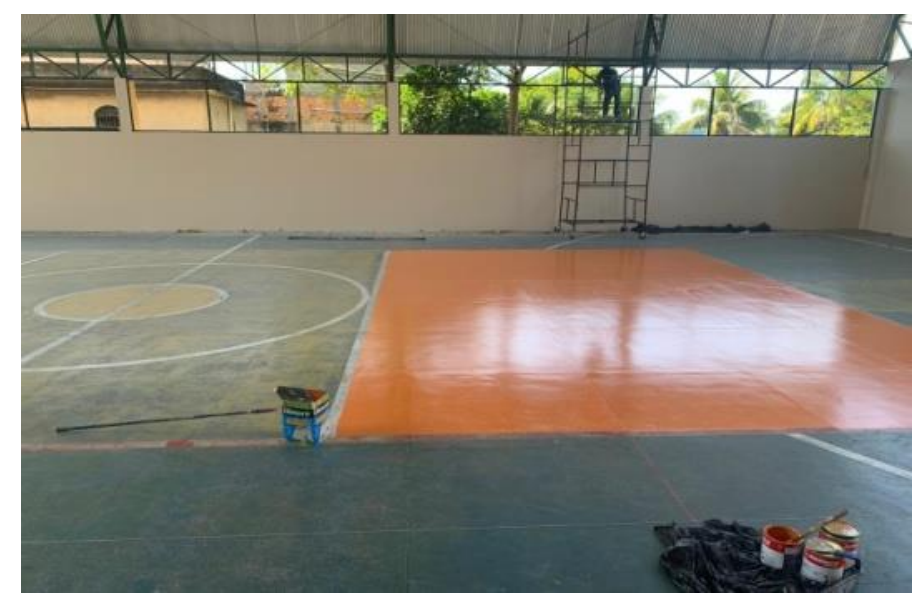

Figure 5: Worker on scaffolding in the height of 2 meters. Source: Authors, (2019).

\section{RESULTS AND DISCUSSION}

As the data collected was proposed the implementation of the regulatory rule no. 35 for the company described, with the following step:

1) Make the prior assessment to find out what and where are the risks related to fall inside the construction site. Request specific medical examinations to work at height. For both, the NR 35 requires hear all activities that will happen during the work. This procedure must be done by professional work safety enabled.

2) Assign responsibilities as the NR 35, when prior assessment, it's time to determine responsibilities. For NR 35, both the company as an employee have responsibility in avoiding accidents with drop in height.

3) Educate workers about the NR 35, after assigning responsibilities, we need to ensure that people know what to do. Therefore, an important step in the implementation of NR 35 concerns the capacity building and training. The responsibility to train the employees of the company. Is the contractor must offer training for your employees perform the work at height. Ensure the program is practical and theoretical training. The minimum hours are 8 hours. Classes must happen within working hours.

4) Require the use of PPE specified by NR 35, awareness should involve the importance of personal protective equipment. The use of PPE is critical to the successful implementation of NR 35. Also, in this case the responsibilities are shared. The employer is obliged to provide and the employee is required to wear PPE determined by NR 35. According to NR 6, "the company is required to provide free of charge to employees the appropriate PPE to the risk. The PPE must be in perfect condition and operation.
5) Keep always updated procedures as well as any process, security procedures need to be updated periodically. Only in this way will remain valid and efficient to ensure safe work at height. The NR 35 requires that the company provide up-to-date information about the risks and control measures. And this is not done only by preliminary security dialogue, which precedes each activity. When new solutions to carry out work at height are adopted, the worker needs to be updated. That means investing in courses, training and guidance in accordance with the requirements of NR 35.

6) Archive and organize the documentation that the company complied with all the requirements of NR 35 , have to prove that to the surveillance. And not just during the work, but for up 25 years after your conclusion. Ensure that documents are always organized and archived in a secure location. The use of management systems helps in this task.

7) Count on the aid of technology to manage is very beneficial to construction companies keep full control over the requirements of NRs, in particular the NR 35. To increase process efficiency, it is possible to use automated systems

Such steps take place in review the programmed procedures, revise the procedures programmed with study and planning of actions to perform and equalize the understanding to eliminate doubts and adopt safe working practices. Warn about other possible risks and not foreseen in the previous security instructions and discuss the Division of tasks and responsibilities, and list potential problems that result in changes in the service or procedures and identify real problems and that may have been ignored during the selection of work safety equipment, disseminate knowledge to create motivation and engagement. After the preliminary assessment, it's time to determine responsibilities for each. For NR 35, both the company as an employee have responsibility in avoiding accidents with drop in height. To meet the requirements of NR 35, it is essential to check whether the company has authorization process for workers who perform work at height, if it causes all work at height is carried out under supervision.

The format of supervision is defined by risk analysis. In other words, consider the peculiarities of each activity. If the same account with processes for organizing and archiving of documentation provided by NR 35, with processes for organizing and archiving of documentation by NR 35 if the same did the risk analysis (RA) and, where applicable, the issuance of the work permit (EN ). To avoid accidents in work at height, NR 35 requires that employees also do your part and follow the norm: Exercise your right to refuse when they find that there are serious and imminent risks. The NR 35 requires that the worker report the fact immediately to your superior, ensure both the safety of your other people affected by your actions or omissions at work and comply with the requirements of NR 35 on work at height and collaborate with the employer in the implementation of security measures required by NR 35 .

The awareness of workers about the NR 35 is very important to assign responsibilities, it is necessary to ensure about what to do. The NR 35 determines that the content of training must contain a minimum of rules and regulations applicable to the work at height, risk analysis and preventing conditions, potential hazards inherent to the work at height, Prevention and control and systems, equipment and procedures for collective protection. However, after the analysis of the visit we found that it is necessary the implementation of NR 35, viewed the improvement of safety and awareness of same, considering that most of the time the lack of preparation of the professionals result and big accidents. 


\section{CONCLUSIONS}

Over the years, the search for worker protection has become in the construction industry, in view of the constant concern for the safety of the worker, because the thread does not have a culture and not make this issue as important

Thus, the need to use the knowledge in the relentless pursuit of solutions, through the improvement of security and the use of EPI's, be they individual or collective, however, what is observed is that even providing safe conditions of work and safety equipment, we still need to train the employee to the execution of its activities, as well as inspect it. This protection must be applied to all those who make the work happen, from the developer to the President of a construction company.

Taking as a basis the regulatory norms, which we assist in the preparation of plans, safety projects, work orders, etc. and who are always evolving to increasingly help us avoid greater risks This work then sought to show prevention measures for working at heights that enable the minimization of accidents at work and to preserve the integrity of the health of workers from the analysis and highlights analyzed in the study, it is recommended the implementation of regulatory standard for this company and collection of responsible for preventive actions, technical requirements and standards, to eliminate and/or minimize the incidence and accidents, unsafe acts and unsafe conditions.

\section{ACKNOWLEDGMENTS}

God who taught me along this walk that was never luck, was always He, everything is for him, everything is from Him, who allowed me to realize a dream that was no longer my, yes it is a beautiful dream he had for my life, yet he all my gratitude For life and achievements.

My mother Francisca Nilza Ribeiro da Silva who never absolutely denied me nothing that has given up countless dreams and achievements to devote to my projects. To my father, Arnaldo Alves Taumaturgo who taught me to be strong, warrior, and that my mind and me to my person gave me the opportunity to become what I am to my brother Mateus da Silva Taumaturgo who is alongside all the achievements of our family.

Thank you for the Cardoso de Mattos-Fassera Higher Education Institute and the professionals who contributed to this work.

\section{REFERENCES}

[1] Chiavenato, I. Recursos Humanos. 5 Ed. São Paulo: Atlas, 2002.

[2] Chiavenato, I. Recursos Humanos. 5 Ed. São Paulo: Atlas, 2009.

[3] Portal Brasil. (Ed.). O Brasil é o maior gerador de energia eólica da América Latina. 2017.

[4] Feiten, 2015 m. e et al. identificação de práticas de gestão de segurança e saúde no trabalho em obras civis. Ambiente Construído, Londres, v. 13, n. 3, p. 43-58, 2013.

[5] Saliba, Tuffi Messias. Curso básico de segurança e higiene ocupacional. 4a Edição. São Paulo. LTR, 2011.

[6] Patton, J .; Cruz, 1. gestão de pessoas: rotinas de trabalho manual. 5 ed. Londres: Senac / DF, 2011.
[7] Miguel, Alberto Sergio s. r. Manual de higiene e segurança. 11 ed. Portugal: Porto Editora Ltda, 2010. 454.

[8] Portal Brasil, http://www.portalbrasil.net/, 2017. 